\title{
Application on One-at-a-Time Sensitivity Analysis of Semi-Distributed Hydrological Model in Tropical Watershed
}

\author{
K. Khalid, M. F. Ali, N. F. Abd Rahman, and M. R. Mispan
}

\begin{abstract}
A soil and water assessment tool (SWAT) model has been employed for the Langat River basin, Malaysia to predict stream flows. The basin was divided into 27 sub basins comprising 193 hydrological response units. Monthly calibration and validation were performed using the measured discharge data of the Kajang station. One-at-a-time sensitivity analysis using Sequential Uncertainty Fitting (SUFI-2) algorithms was performed to examine the critical input variables of the study area. It was found that the SWAT model can be successfully applied for hydrological evaluation of the basin and the SCS runoff curve number, base flow alpha factor and groundwater delay were found to be the most sensitive parameters. The next step should be conducting a 30 years continuous hydrological modeling. It is needed to analyze the water balance and the hydrological trends of the basin due to the basin experienced major land used changes since 1980 for urbanization activities.
\end{abstract}

Index Terms-One-at-a-time sensitivity analysis, hydrological modeling, langat river basin, SUFI-2 algorithms.

\section{INTRODUCTION}

The concept of watershed modeling is embedded in the interrelationships of geospatial and hydro-meteorological data and represented through mathematical abstractions. The behaviour of each process is controlled by its own characteristics as well as by its interaction with other processes active in the catchment. The predominant hydrologic processes include rainfall, interception, evapo-transpiration, infiltration, surface runoff, percolation and subsurface flow. These models vary from empirical models to stochastic models of various kinds and finally to the more recent distributed models. In recent years, distributed watershed models have been increasingly used to implement alternative management strategies in the areas of water resource allocation, flood control, impact assessments for land use and climate change, and pollution control. Many of these models share a common base in their attempt to incorporate the heterogeneity of the watershed and the spatial distribution of topography, vegetation, land use, soil characteristics, rainfall, and evaporation. Such models include Hydrologic Engineering Centre-The Hydrologic

Manuscript received June 16, 2014; revised September 20, 2014

K. Khalid, M. F. Ali, and N. F. Abd Rahman are with the Faculty of Civil Engineering, Universiti Teknologi MARA, Shah Alam, Selangor, Malaysia (e-mail: khairikh@pahang.uitm.edu.my, mdfozi@salam.uitm.edu.my, doctor cute84@yahoo ).

M. R. Mispan is with the Strategic Resources Research Centre, Malaysian Agricultural Research and Development Institute (MARDI), Serdang, Selangor, Malaysia (e-mail: radzali@mardi.gov.my).
Modeling System (HEC-HMS) [1], Agricultural non-point source (AGNPS) [2], Hydrological Simulation Program-Fortran (HSPF)[3], European hydrological system (MIKE SHE) [4], and Soil Water Assessment Tool (SWAT)[5].

It was reported that in Malaysia, the Stormwater Management Model (SWMM) and Info Works Collection System (CS) are among the most widely used software to model drainage systems [6]. But many more hydrological models were found in the literature have been utilized for the watershed modeling study in the country. These included a Hydrologic Engineering Centre-The Hydrologic Modeling System (HEC-HMS) software [7]-[11]; followed was the MIKE SHE models [12] and finally the most current model is the Soil Water Assessment Tools (SWAT) software [13], [14]. Among these models, the physically based distributed model SWAT is well established for analyzing the impacts of land management practices on water, sediment, and agricultural chemical yields in large, complex watersheds [15]. SWAT has been successfully used by researchers around the world for distributed hydrologic modeling and management of water resources in watersheds with various climates and terrain characteristics. Comprehensive review of SWAT model applications, calibrations and validations are given by [16], [17]. SWAT has many parameters to be calibrated on the stream flow, sediment and for other environmental purposes. In order to calibrate a stream flow alone, SWAT needs to consider about 26 related input parameters [18]. The calibration of such a distributed parameterized watershed model is beset with a few serious issues that deserve the attention and careful consideration of researchers, especially concerning uncertainty.

Langat River basin, a tropical river watershed in Malaysia is chosen for the study in accessing the critical input parameters of the SWAT model. Several studies have been conducted on the basin related to water resources and hydrological behavior of the basin. The basin became a first watershed in the country is initiated towards implementing of Integrated River Basin Management (IRBM) [19]. Many researchers were studied on the hydrological processes of the basin include a historical water discharges study [20]; the impact of land used change on discharge and direct runoff [21]-[24]; sustainable groundwater resources and environmental management [25]; the flood hazard mapping [26], [27]; the water supply [28], [29]; water quality [30] and a river bed properties study of the river basin [31], [32]. The most current in early 2014, the upper part of the basin was experienced the ammonia pollution due to the effluent 
discharged by the nearby factories. The pollution was caused for two months closure of two main water treatment plants. During a dry season, government was implemented a water rationing programme due to a major decrease water level of dams in the state of Selangor including the Sungai Langat dam. All these studies and information show the important and a need of widespread sustainable water resources management in the Langat River basin. Comprehensive watershed models are expected to be effective tools to aid the sustainable management of land and water resources in the Langat River basin. To successfully apply hydrological models in practical water resource investigations, careful calibration and prediction uncertainty analysis are required. The study was used a Sequential Uncertainty Fitting (SUFI-2) method in order to calibrate parameters and analyze uncertainty, including performing one-at-a-time sensitivity analysis of SWAT model.

\section{STUDY AREA}

Langat River basin occupies the south and south-eastern parts of Selangor, and small portion of Negeri Sembilan and Wilayah Persekutuan, Malaysia. The main stream of the Langat River which stretches for $141 \mathrm{~km}$ has a total catchment area of $2271 \mathrm{~km}^{2}$ and lies within latitudes of $2^{\circ} 40^{\prime} 152^{\prime \prime} \mathrm{N}$ to $3^{\circ} 16^{\prime} 15^{\prime \prime} \mathrm{N}$ and longitudes of $101^{\circ} 19^{\prime} 20^{\prime \prime} \mathrm{E}$ to $102^{\circ} 1$ ' $10^{\prime} \mathrm{E}$. The main tributary, Langat River flows from the main range (Titiwangsa Range) at the Northeast of Hulu Langat District in south-southwest direction and draining into the Straits of Malacca as in Fig. 1. Topographically, this basin can be divided into three geographic regions, i.e. the mountainous area of the north, the undulating land in the centre of the basin and the flat flood plain at the downstream of Langat River. The upper part of the basin is selected as a study area. The industrial sector is also minimal in the study area. The average rainfall is about $2400 \mathrm{~mm}$, and the highest months (April and November) show rainfall amount above $250 \mathrm{~mm}$, while the lowest is in June, about the average of $100 \mathrm{~mm}$.

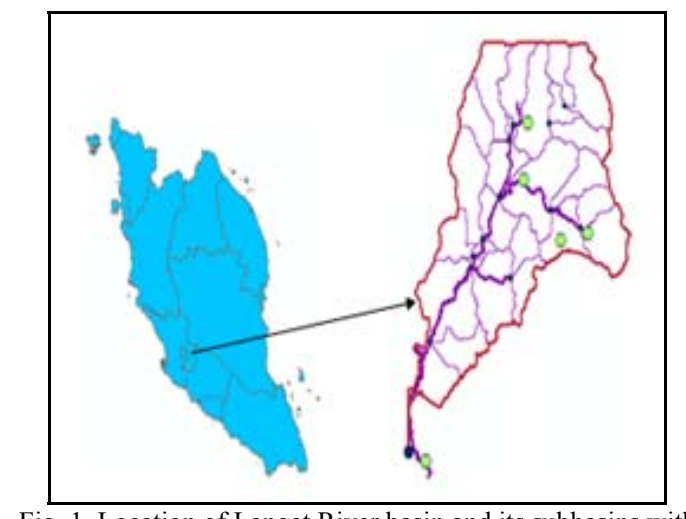

Fig. 1. Location of Langat River basin and its subbasins with hydro-meteorological stations.

\section{Methods And Materials}

SWAT (Soil Water Assessment Tool) is continuous time, spatially distributed model designed to simulate water, sediment, nutrient and pesticide transport at a catchment scale on a daily time step. It uses hydrologic response units
(HRUs) that consist of specific land use, soil and slope characteristics. The HRUs are used to describe the spatial heterogeneity in terms of land cover, soil type and slope class within a watershed [33]. The model estimates relevant hydrologic components such as evapo-transpiration, surface runoff and peak rate of runoff, groundwater flow and sediment yield for each HRUs unit. SWAT is embedded in a GIS interface. The hydrologic cycle simulated by SWAT is based on the Water Balance Equation (1).

$$
S W_{t}=S W_{O}+\sum_{i=1}^{t}\left(R_{d a y}-Q_{\text {surf }}-E_{a}-W_{\text {seep }}-Q_{q w}\right)
$$

In which, $S W_{t}$ is the final soil water content (mm water), $S W_{o}$ is the initial soil water content in day $i$ (mm water), $t$ is the time (days), $R_{\text {day }}$ is the amount of precipitation in day $i$ (mm water), $Q_{\text {surf }}$ is the amount of surface runoff in day $i(\mathrm{~mm}$ water), $E_{a}$ is the amount of evapotranspiration in day $i(\mathrm{~mm}$ water), $W_{\text {seep }}$ is the amount of water entering the vadose zone from the soil profile in day $i$ (mm water), and $Q_{g w}$ is the amount of return flow in day $i$ ( $\mathrm{mm}$ water). To estimate surface runoff two methods are available. These are the SCS curve number procedure USDA Soil Conservation Service [33] and the Green \& Ampt infiltration method [34]. In this study, the SCS curve number method was used to estimate surface runoff. Hargreaves method was used for estimation of potential evapo-transpiration (PET) [35]. The SCS curve number is described by Equation (2).

$$
Q_{\text {surf }}=\frac{\left(R_{\text {day }}-0.2 S\right)^{2}}{\left(R_{d a y}+0.8 S\right)}
$$

In which, $Q_{\text {surf }}$ is the accumulated runoff or rainfall excess $(\mathrm{mm}), R_{\text {day }}$ is the rainfall depth for the day $(\mathrm{mm}), S$ is the retention parameter $(\mathrm{mm})$. The retention parameter is defined by Equation (3).

$$
S=25.4\left(\frac{100}{C N}-10\right)
$$

The SCS curve number is a function of the soil's permeability, land used and antecedent soil water conditions.

\section{SWAT MODEL INPUT AND SETUPS}

The spatially distributed data (GIS input) needed for the ArcSWAT interface include the Digital Elevation Model (DEM), soil data, land use and stream network layers. Data on weather and observed stream flow were also used for prediction of stream flow and calibration purposes. DEM was derived mainly from a contour map of $20 \mathrm{~m}$ interval in a shape file format and a digital river network, which were provided by Department of Survey and Mapping Malaysia (JUPEM).

The land used map of a study area was obtained from Department of Agriculture, Malaysia. The land use map needs to be reclassified according to the specific land cover types such as type of crop, pasture and forest. The dominant land used in the study area is a primary forest reserve $(64.80 \%)$, followed by rubber $(18.04 \%)$, urban area $(7.58 \%)$, and orchard agriculture (3.69\%).

The SWAT model requires different soil textural and physicochemical properties such as soil texture, available 
water content, hydraulic conductivity, bulk density and organic carbon content for different layers of each soil type. These data were obtained from Department of Agriculture, Malaysia. The majority of the study area is covered by a steepland (64.8\%) and followed by a Renggam-Jerangau soil series (23.20\%), Telemong-Akob-Local Alluvium (8.00\%) and Munchong-Seremban (3.24\%). Fig. 2 shows the soil types of the study area.

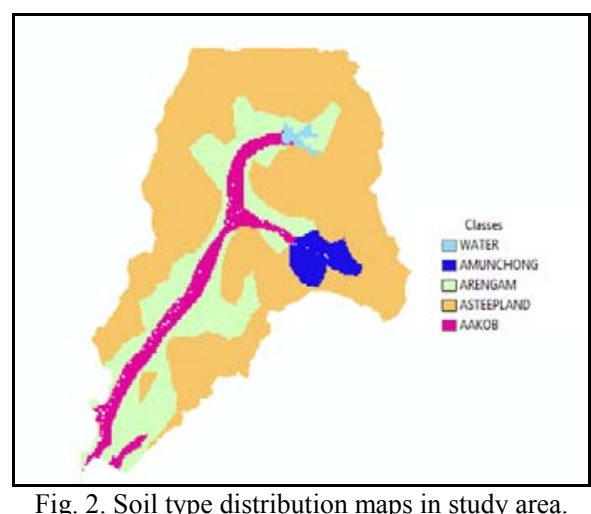

SWAT requires daily meteorological data that can either be read from a measured data set or be generated by a weather generator model. The weather variables used in this study are daily precipitation, minimum and maximum air temperature for the period 1999-2010. These data were obtained from the Department of Irrigation and Drainage (DID) and Department of Environment (DOE), Malaysia for stations located within and around the watershed (Fig. 1). A weather generator developed by [36] was used to fill the gaps due to missing data. Daily river discharge values for Kajang streamflow station were obtained from the Department of Irrigation and Drainage (DID) Malaysia.

The model setup involved five steps: 1) data preparation; 2) subbasin discretization: 3) HRU definition; 4) parameter sensitivity analysis; 5) calibration and uncertainty. The subbasin discretization only focused on the $305.3 \mathrm{~km}^{2}$ upper part of the Langat River basin as in Fig. 1. The parameter sensitivity analysis was done using the ArcSWAT interface for the whole catchment area [37]. Twelve hydrological parameters were tested for one-at-a-time sensitivity analysis for the simulation of the stream flow in the study area. Table I shows the most frequent input parameters were used in the calibration process of surface runoff and baseflow as been reported in previous 64 selected SWAT watershed studies [17]. The calibration and uncertainty analysis were conducted using a Sequential Uncertainty Fitting (SUFI-2) algorithm [38], [39].

After setting up the model, the default simulations of stream flow using the default parameter values were conducted in the Langat River basin for the calibration period. The default simulation outputs were compared with the observed streamflow. In this study the automatic calibration was done after the model was manually calibrated and reached to stage that the differences between observed and simulated flows were minimized and shown improved objective function values. The simulation was used 12 years daily rainfall data with the first two years, starting from 1 January 1999 to 31 December 2000 were utilized for the model warm-up, followed by next five years for model calibration and will end by following next five years data validation processes. Only the results of a default streamflow simulation outputs and details of one-at-a-time sensitivity analysis using the SUFI-2 algorithm of input parameters were reported in this paper.

TABLE I: SELECTED INPUT PARAMETER OF SWAT MODEL

\begin{tabular}{|c|c|c|c|}
\hline No. & $\begin{array}{c}\text { Input } \\
\text { Parameter }\end{array}$ & Description of Parameter & $\begin{array}{c}\text { Min and Max } \\
\text { Range }\end{array}$ \\
\hline 1 & $\mathrm{CN} 2$ & SCS runoff curve number & $35-98$ \\
\hline 2 & OV_N & $\begin{array}{c}\text { Manning's "n" value for } \\
\text { overland flow }\end{array}$ & $0.01-30$ \\
\hline 3 & AWC & $\begin{array}{l}\text { Available water capacity } \\
\text { of the soil layer (mm H2O } \\
\text { /mm soil) }\end{array}$ & $0-1$ \\
\hline 4 & ESCO & $\begin{array}{l}\text { Soil evaporation } \\
\text { compensation factor }\end{array}$ & $0-1$ \\
\hline 5 & EPCO & $\begin{array}{l}\text { Plant uptake } \\
\text { compensation factor }\end{array}$ & $0-1$ \\
\hline 6 & SURLAG & $\begin{array}{l}\text { Surface runoff lag time } \\
\text { (days) }\end{array}$ & $0.05-24$ \\
\hline 7 & ALPHA_BF & $\begin{array}{l}\text { Baseflow alpha factor } \\
\text { (days) }\end{array}$ & $0-1$ \\
\hline 8 & GW_REVAP & $\begin{array}{c}\text { Groundwater "revap" } \\
\text { coefficient }\end{array}$ & $0.02-0.2$ \\
\hline 9 & GW_DELAY & Groundwater delay (days) & $0-500$ \\
\hline 10 & GW_QMN & $\begin{array}{l}\text { Threshold depth of water } \\
\text { in the shallow aquifer } \\
\text { required for return flow to } \\
\text { occur (mm) }\end{array}$ & $0-5000$ \\
\hline 11 & REVAP_MN & $\begin{array}{l}\text { Threshold depth of water } \\
\text { in the shallow aquifer for } \\
\text { "revap" to occur (mm) }\end{array}$ & $0-500$ \\
\hline 12 & RCHARG_DP & $\begin{array}{l}\text { Deep aquifer percolation } \\
\text { fraction }\end{array}$ & $0-1$ \\
\hline
\end{tabular}

\section{Default Simulation and Manual Calibration}

The comparison of default simulation output with the observed streamflow data about the Kajang streamflow station showed an agreement between the observed and simulated flow results. Parameters manually adjusted to be an evaporation compensation factor (ESCO), curve number (CN2), available water holding capacity of the soil layer (Sol_AWC, $\mathrm{mm} / \mathrm{mm}$ ), saturated hydraulic conductivity (Sol_K, mm/hr) and surface runoff lag time. The manual calibration was time intensive, but it helped to get better automatic calibration results. A calibration output obtained as in Fig. 3 shows simulated streamflowis lying slightly above the observed value. A value of coefficient of determination, $\mathrm{R}^{2}$ of 0.69 was gained on a simulations and the value can be considered as good achievement of the manual calibration processes and minimal enough to access sensitivity of input parameters using one-at-a-time sensitivity analysis method.

\section{ONE-AT-A-TIME SENSITIVITY ANALYSIS}

There are a few methods available in assessing a sensitivity of input parameters in hydrological models. In SWAT model, input parameters can be either manually adjusted in the SWAT model or can be accessed in the SWAT-CUP. SWAT-CUP is a computer program for calibration of SWAT models and the programs link SUFI-2 
algorithms to SWAT. It enables sensitivity analysis, calibration, validation, and uncertainty analysis of SWAT models.

In SUFI-2, parameter uncertainty accounts for all sources of uncertainties such as uncertainty in driving variables, conceptual model, parameters, and measured data. The degree to which all uncertainties are accounted for is quantified by a measure referred to as the P-factor, which is the percentage of measured data bracketed by the $95 \%$ prediction uncertainty (95PPU). Another measure quantifying the strength of a calibration/uncertainty analysis is the $\mathrm{R}$ factor, which is the average thickness of the 95PPU band divided by the standard deviation of the measured data. SUFI-2, hence seeks to bracket most of the measured data with the smallest possible uncertainty band. The 95PPU is calculated at the $2.5 \%$ and $97.5 \%$ levels of the cumulative distribution of an output variable obtained through Latin hypercube sampling, disallowing $5 \%$ of the very bad simulations [39]. Theoretically, the value of the $\mathrm{P}$ factor ranges between 0 and $100 \%$, while that of $\mathrm{R}$-factor ranges between 0 and infinity. A P-factor of 1 and R-factor of zero is a simulation that exactly corresponds to measured data.

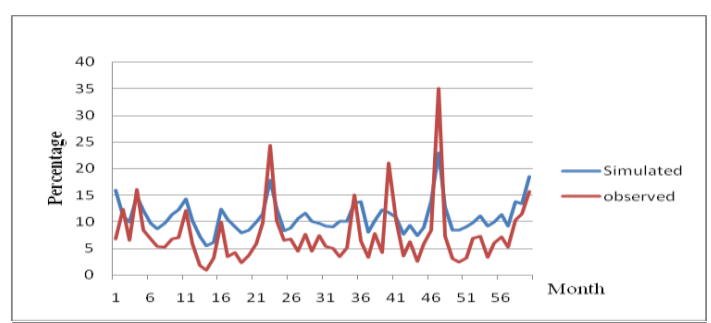

Fig. 3. SWAT five years streamflow simulation output.

TABLE II: SUMMARY OF ONE-AT-A-TIME SENSITIVITY ANALYSIS

\begin{tabular}{ccccc}
\hline \hline No. & Input Parameter & $\begin{array}{c}\text { Best Fitted } \\
\text { Value }\end{array}$ & $\mathrm{R}^{2}$ & $\begin{array}{c}\text { Sensitivity } \\
\text { Ranking }\end{array}$ \\
\hline 1 & CN2 & 66.5 & 0.03000 & 1 \\
2 & OV_N & 3.009 & 0.00400 & 11 \\
3 & AWC & 0.1 & 0.00407 & 8 \\
4 & ESCO & 0.5 & 0.00407 & 8 \\
5 & EPCO & 0.1 & 0.00407 & 8 \\
6 & SURLAG & 16.815 & 0.00410 & 7 \\
7 & ALPHA_BF & 0.7 & 0.01964 & 3 \\
8 & GW_REVAP & 0.182 & 0.00430 & 6 \\
9 & GW_DELAY & 450 & 0.02100 & 2 \\
10 & GW_QMN & 1500 & 0.04700 & 4 \\
11 & REVAP_MN & 50 & 0.00390 & 12 \\
12 & RCHARG_DP & 0.9 & 0.04600 & 5 \\
\hline \hline
\end{tabular}

One-at-a-time sensitivity shows the sensitivity of a variable to the changes in a parameter if all other parameters are kept constant at some value. Table II shows the summary of one-at-a-time sensitivity analysis for all the twelve input parameters. Ten iterations were conducted for each input parameter in order to gain the best fitted input value and overall coefficient of determination. SCS runoff curve number (CN2) was found to be the most sensitive parameters for a Langat River basin. The finding was observed agreed to a first input parameter need to be adjusted using SWAT manual calibration flowchart as conducted by previous researchers [17]. Other two most sensitive input parameters were a groundwater delay (GW_Delay) and base flow alpha factor (ALPHA_BF). A comparison of input parameters on a one-at-a-time sensitivity analysis shows as in Fig. 4.

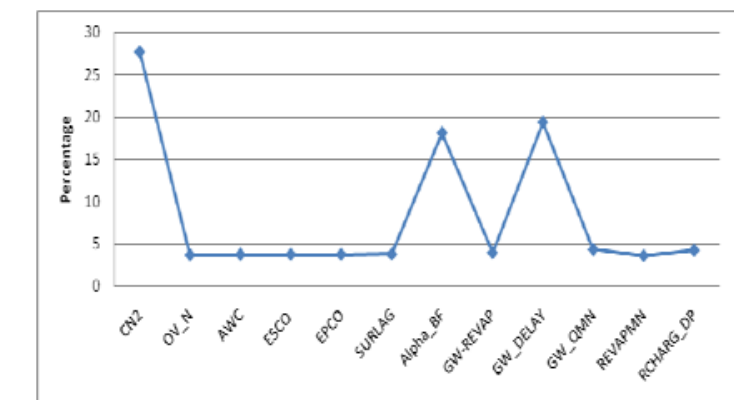

Fig. 4. Comparison of input parameters on a one-at-a-time sensitivity analysis.

\section{CONCLUSION}

A stream flow of the upper part of the Langat River basin was successfully modeled by the version of Soil and Water Assessment Tool (SWAT), ArcSWAT2009.93.b embedded in ArcGIS 10. The SCS runoff curve number (CN2), base flow alpha factor (ALPHA_BF) and groundwater delay (GW_Delay) were found to be the most sensitive input parameters by using the SUFI-2 algorithm. This model needed further adjustment on input data by including other soil parameters comprise of a saturated hydraulic conductivity, moist bulk density USLE equation soil erodibility (K) factor and moist bulk density into one-at-a-time sensitivity analysis. Though the one-at-a-time sensitivity analysis able to show the sensitivity of a variable to the changes in a parameter, but nobody knows what the exact value of those other constant parameters should be. Analysis for a number of input parameters simultaneously in the sensitivity analysis is recommended to confirm the one-at-a-time sensitivity analysis.

\section{ACKNOWLEDGMENT}

The project was supported by the Exploratory Research Grant Scheme (ERGS), Ministry of Education, and Universiti Teknologi MARA (UiTM), Malaysia.

\section{REFERENCES}

[1] A. S. William and J. F. Fleming, Hydrologic modeling system HEC-HMS User's Manual, U.S. Army Corps of Engineers, Aug. 2010, pp. 306.

[2] R. A. Young, C. A. Onstad, D. D. Bosch, and W. P. Anderson, "AGNPS: An agricultural nonpoint source pollution model: A large watershed analysis tool," Conservation Research Rep, U.S. Department of Agriculture, Washington, DC, vol. 35, 1987.

[3] B. R. Bicknell, J. C. Imhoff, J. L. Kittle, T. H. Jobes, and A. S. Donigian, Hydrologic Simulation Program - FORTRAN (HSPF), User's Manual for Version, 2001.

[4] M. B. Abbott, J. C. Bathurst, J. A. Cunge, P. E. O’Connell, and J. Rasmussen, "An introduction to the european hydrological system=systeme hydrologique european 'SHE'. 1: history and philosophy of a physically based Distributed modeling system," Journal Hydrol, vol. 87, pp. 45-59, 1986.

[5] J. G. Arnold, R. Srinivasan, R. R. Muttiah, and J. R. Williams, "Large area hydrologic modeling and assessment part 1, Model development," Journal AM Water Resour. Assoc., 1998, vol. 34, no.1, pp. 73-89.

[6] Y. S. Liew and Z. Selamat, "Review of urban stormwater drainage system management," Malaysia Water Research Journal, vol. 1, pp. 22-32, 2011 
[7] S. Alaghmand, R. Abdullah, I. Abustan, M. A. M. Said, and B. Vosoogh, "GIS-Based river basin flood modelling using HEC-HMS and MIKE 11 - Kayu Ara river basin, Malaysia," Journal of Environmental Hydrology, vol. 20, 2012.

[8] Y. M. Mustafa, M. S. M. Amin, T. S. Lee, and A. R. M. Shariff, "Evaluation of land development impact on the tropical watershed hydrology using remote sensing and GIS," Journal of Spatial Hydrology, vol. 5, no. 2 pp. 16-30, 2011.

[9] S. Supiah, S.A.R. Dan'azumi, and A. Mohamad, "Uncertainty analysis of HEC-HMS model parameters for Southern Malaysia," in Proc. the 1st. IWA Malaysia Young Water Professionals Conference), pp. 2-4, 2010.

[10] P. Y. Julien, A. A. Ghani, N. A. Zakaria, R. Abdullah, and C. K. Chang, "Case study: flood mitigation of the Muda river, Malaysia." Journal of Hydraulic Engineering, 2010, pp. 251-261.

[11] Z. Yusop, C. H. Chan, and A. Katimon, "Runoff characteristics and application of HEC-HMS for modelling stormflow hydrograph in an oil palm catchment," Water Science \& Technology, 2007, vol. 56, no. 8 . pp. 41-48.

[12] A. B. E. Rahim, I. Yusoff, A. M. Jafri, Z. Othman, and A. Ghani, "Application of MIKE SHE modelling system to set up a detailed water balance computation," Water and Env Journal, vol. 26, 2012, pp 490-503.

[13] A. H. Lai and F. Arniza, "Application of SWAT Hydrological Model to Upper Bernam River Basin, Malaysia," IUP Journal of Env. Sciences, 2011, vol. 5, no. 2 , pp. 7-19.

[14] K. R. Ayub, L. S. Hin, and H. A. Aziz, "SWAT Application for hydrologic and water quality modeling for suspended sediments; A case study of Sg. Langat's Catchment in Selangor," in Proc. the International Conference on Water Resources (ICWR), 2009, pp. 1-7.

[15] J. G. Arnold and N. Fohrer, "SWAT2000: Current capabilities and research opportunity in applied modeling," Hydrol, 2005, vol. 19, no. 3 , pp. 563-572.

[16] P. W. Gassman, M. R. Reyes, C. H. Green, and J. G. Arnold, "The soil and water assessment tool: Historical development, applications, and future directions," Trans. ASABE, 2007, vol. 50, no. 4, pp. 1211-1250.

[17] J. G. Arnold, D. N. Moraisi, P. W. Gassman, K. C. Abbaspour, M. J. White, R. Srinivasan, C. Santhi, R. D. Harmel, A. V. Griensven, M. W. V. Liew, N. Kannan, and M. K. Jha, "SWAT: Model use, calibration, and validation," Trans. ASABE, 2012, vol. 55, no. 4, pp. 1491-1508.

[18] P. Shi, Y. Hou, T. Xie, C. Chen, X. Chen, Q. Li, S. Qu, X. Fang, and R. Srinivasan, "Application of a SWAT model for Hydrological modeling in the Xixian watershed, China," Journal Hydrol. Eng., 2013, vol. 18, pp. 1522-1529.

[19] M. B. Mokhtar, R. Elfithi, and A. H. H. Shah, "Collaborative decision making as a best practice in integrated water resources management; A case study on Langat basin, Malaysia." in Proc. the 1st Southeast Asia Water Forum, Chiangmai, Thailand, 2004, pp. 333-354.

[20] H. Y. Hai, O. Jaafar, A. E. Shafie, and S. A. S. Mastura, "Analysis of hydrological processes of langat river sub basins at lui and dengkil," International Journal of the Physical Sciences, 2011, vol. 6, no. 32, pp. 7390-7409.

[21] J. Hafizan, M. Z. Sharifuddin, Z. A. Ahmad, K.Y. Mohd, A. S. Mohd, and M. Mazlin, "Hydrological trend analysis due to land use changes at Langat River Basin," Environment Asia 3(special issue), 2010, pp. 20-31.

[22] A. Amini, M. A. Thamer, G. A. Halim, and K. H. Bujang, "Adjustment of peak streamflows of a tropical river for urbanization," American Journal of Environmental Sciences, 2009, vol. 5, no. 3, pp. 285-294.

[23] O. Jaafar, "Kajian kesan penggunaan guna tanah terhadap sumber air lembangan Sg. Langat melalui integrasi data penderiaan jauh satelit dan GIS serta permodelan hidrologi," Ph.D Thesis, Department of Civil, Built and Environmental Engineering, Universiti Kebangsaan Malaysia, 2007.

[24] K. Khalid, M. F. Ali, N. F. A. Rahman, and M. Z. A. Rasid, "The importance and role of infiltration approaches in hydrological modeling; A case study in Malaysia river basin," in Proc. International Colloquium on Science and Technology 2014 (ICOST 2014), pp. 76-80, 2014.

[25] M. Thant and P. Corporation, The study on the Sustainable Groundwater Resources and Environmental Management for the Langat Basin in Malaysia, 2002, vol. 1-5.

[26] L. Billa, S. Mansor, and A. R. Mahmud, "Pre-flood inundation mapping for flood early warning," Journal of Flood Risk Management, 2011.

[27] J. Abdullah, "Distributed runoff simulation of extreme monsoon rainstorms in Malaysia using TREX," Ph.D thesis, Department of Civil and Environmental Engineering, Colorado State Univ., Fort Collins, Colorado, 2013

[28] M. F. Ali, A. Saadon, N. F. A. Rahman, and K. Khalid, "An assessment of water demand in Malaysia using water evaluation and planning (WEAP) system," in Proc. the International Civil and Infrastructure Engineering Conference, pp. 22-24, 2013.

[29] T. Kta, Sungai Langat Integrated River Basin Management Study, CS-SG119.KTA Tenaga Sdn. Bhd, Kuala Lumpur, Malaysia, 2005.

[30] M. F. Ali, N. F. A. Rahman, and K. Khalid, "Discharge assessment by using integrated hydrologic model for environmental technology development," in Proc. the 4th International Conference on Key Engineering Materials (ICKEM 2014), pp. 22-23, Bali.

[31] A. A. Ghani, N. A. Zakaria, C. K. Chang, J. Ariffin, Z. A. Hassan, and A. B. A. Ghaffar, "Revised equations for Manning's coefficient for sand-bed rivers," International Journal River Basin Management, vol. 5, no. 4, 2007, pp. 329-346.

[32] H. M. Azamathulla, K. C. Chun, A. A. Ghani, J. Ariffin, N. A. Zakaria, and Z. A. Hassan, "An ANFIS-based approach for predicting the bed load for moderately sized rivers," Journal of Hydro-Environment Research, 2009, pp. 35-44.

[33] USDA Soil Conservation Service, National Engineering Handbook Section 4 Hydrology, 1972, Chapters 4-10.

[34] W. H. Green and G. A. Ampt, "Studies on soil physics-The flow of air and water through soils," Journal Agric Science, vol. 4, pp. 11-24. 1911.

[35] G. L. Hargreaves and J. P. Riley, "Agricultural benefits for Senegal River basin," Journal Irrig Drain Eng, 1985, vol. 111, no. 2, pp. 113-124.

[36] J. Schuol and K. C. Abbaspour, "Using monthly weather statistics to generate daily data in a SWAT model application to West Africa," Ecol Model, 2007, vol. 201, pp. 301-311.

[37] A. V. Griensven, T. Meixner, S. Grunwald, T. Bishop, M. Diluzio, and R. Srinivasan, "A global sensitivity analysis tool for the parameters of multi-variable catchment models," Journal Hydrol, 2006, vol. 324, no. 1-4, pp. 10-23.

[38] K. C. Abbaspour, C. A. Johnson, and M. T. V. Genuchten, "Estimating uncertain flow and transport parameters using a sequential uncertainty fitting procedure," Vadose Zone J, 2004, vol. 3, no. 4, pp. 1340-1352.

[39] K. C. Abbaspour, User Manual for SWAT-CUP, SWAT Calibration and Uncertainty Analysis Programs, Swiss Federal Institute of Aquatic Science and Technology, Eawag, Duebendorf, Switzerland, 2012.

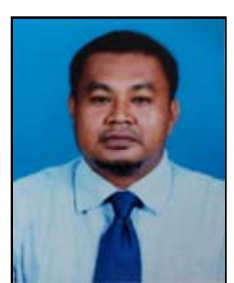

Khairi Khalid is a Ph.D candidate in integrated water resources management at Universiti Teknologi MARA, Shah Alam, Malaysia. Previously, he was a senior lecturer in UiTM, MARA since 2009. He obtained master's degree in environmental engineering from Universiti Kebangsaan Malaysia. He has written and presented several papers for local conferences and international conference as well. His research interest includes hydrologic models in tropic condition as well as sensitivity of geospatial data in hydrological modeling.

Mohd Fozi Ali is an associate professor of water resources management at Universiti Teknologi MARA, Shah Alam, Malaysia. He received his Ph.D from University of Strathclyde, Glasgow. His current research interests include a best management practices in integrated water resources, rain harvesting and domestic water treatment processes.

Nor Faiza Abd Rahman is a Ph.D candidate at Faculty of Civil Engineering Universiti Teknologi MARA, Shah Alam, Malaysia. She completed her master's degree in environmental engineering from Universiti Sains Malaysia. Her research interest includes an impact of climatic changes on the water resources management and sensitivity of meteorological data in hydrological modeling.

Muhamad Radzali Mispan is a principal research officer at Malaysian Agricultural Research and Development Institute (MARDI), Malaysia. He received his Ph.D from University of Notingham, UK. His research interests include the open source geospatial solution, remote sensing technology and online GIS development for land resource management. 